\title{
TURKISH IMAGE IN THE WEST DURING THE OTTOMAN EMPIRE: HISTORICAL FACTS AND PRESENT DAY CONNOTATIONS
}

\author{
Ali Evler ${ }^{1}$ \\ Mehmet Toplu²
}

\section{Introduction}

Once again the history repeats itself when we hear the news about 'Serbian butcher Ratko Miladic', who slaughtered thousands of Bosnians, was convicted of war crimes, genocide, war crimes against humanity and sentenced to life imprisonment by the UN Tribunal. On the day he entered Srebrenica, he had obnoxiously said, "He would take revenge on Muslims" in Bosnia referring them as "Turks". How and where did all this "Taking revenge on each other between Christians and Muslims" story start in the history? When we study about the "Turkish Image" in early modern plays in England, it is as if the same starting point of Linda McJannet when she wanted to write her book The Sultan Speaks. McJannet (2006, viii) tells us how and why she started to write her book in her preface to her book,

As I was reading The Couragious Turke, a university play depicting the conquest of Bosnia-Herzegovina by Murad I. The play dramatizes his victory at Kosovo in 1389 and his subsequent assassination by a wounded Serbian soldier, events to which Slobodan Milosevic frequently referred in his efforts to inflame Serbian Christians against Muslims in the former Yugoslavia. "So," I exclaimed to myself, "that's why they're Muslim!" Apparently, the Ottoman presence in Eastern Europe had not loomed large in my college courses on European history, and I suspect that for most students

\footnotetext{
I Professor at the Hodja Ahmet Yassawi International Kazakh Turkish University, Kazakhstan. E-mail: evleralii@gmail.com.

2 Professor at the Hodja Ahmet Yassawi International Kazakh Turkish University, Kazakhstan. E-mail:mtopluo9@gmail.com.
} 
since then the omission was not remedied until after September II, 200I, if indeed it has been remedied at all.

She is also "...struck by the similarities between the martial rhetoric in histories and plays about the Turks when President George W. Bush responded to the attacks of September II by using the term "crusade". Thus, we are apparently reminded of the conflict dating back to the time of Seljuk Empire and Crusades around I07I-I095 when Seljuk Turks conquered Syria and Palestine, not surprisingly during the earlier Muslim rule, especially during the Umayyad (650-750) and Abbasid (750-969) dynasties as "there was a relative peace and prosperity in the city"3. It all started when the Turks were really considered as a real threat to Istanbul (Constantinople) and to Europe onward. The story perpetuated once again over Turks, in particular Jerusalem just after the First World War when Ottoman Empire gradually went into a state of "The Sick Man of Europe". Several regions of Ottoman Empire, what is Turkey today were occupied by Westerners: Istanbul by England, South East by France, South by Italy, West by Greece. McJannet (2006) refers just at the beginning of her book to two very dramatic incidents when the president of the USA, George W. Bush responded to the attacks of September 20II by using the term "crusade", and Rana Kabbani, author of a study of nineteenth-century travel narratives, "post-Crusader Europe would never wholly emerge from the antagonism [ of ] its "Holy Wars'"4. As late as I920, she reports, the French general Gourand, on arriving at the tomb of the famous Saracen leader in Damascus, “ announced gloatingly, 'Nous revoila, Saladin!' " meaning in English "Saladin, We are back!". These two seemingly notorious incidents prove the long-established both political and military competition between the East and the West, against Muslims even though Turkey has nothing to do with the former incident.

\section{A New Flame in the Conflict: Trump}

Further back in the history, the first encounter of the English with the Ottoman Islamic world (Still not Turkish at the time) in Europe dates back to I396 during The Battle of Nicopolis / the Crusade of Nicopolis. According to Halil Halad $(2013,749)$ The Duke of Lancaster sent his son Bolingbroke ac-

\footnotetext{
3 See the entry: https://en.wikipedia.org/wiki/History_of_Jerusalem. Accessed on November 22, 2017.

4 See the entry: Barr, James. “General Gouraud: ‘Saladin, We're Back!' Did He Really Say It?”. Posted by Joshua on Friday, May 27th, 20I6. http://www.joshualandis.com/blog/general-gouraud-saladin-back-really-say/. Accessed on November, 2017.
} 
companying I000 warriors armed with spears to fight against Bayazid. After the defeat he turned back to England embarking a Venice ship and saved his life.

Thus, with the ever growing military and political power of Ottoman Empire, Turks were seen on stages naturally more as the curiosity about their lifestyle culture increased among the western people. During this period, however, how Muslims, better to say, Ottoman Turks were perceived and presented and what contributed to the creation of this image is our concern. According to Aksoy in her preface to Rönesansingilteresinde Türkler (2004, vii) tarihin çeşitli dönemlerinde Avrupa'nın Türklere karşı tutumu, Osmanlı'nın gücüne, kazandiğı zaferlere bağlı değişmiş, Batı edebiyatında, tiyatrosunda Türk imgesi de aynı doğrultuda şekillenmişstir. Dolayısıyla Avrupa tarihinde ve coğrafyasinda bütünsel bir Türk imgesinden söz etmek güçtür. (It is less likely to have a holistic Turkish image in the Renaissance period. We can say that this image has changed in proportion to the decline and rise of Ottoman Empire. It is a known fact that for the audiences of the period brutal scenes were an inviting factor). In Aksoy 2004, I4:

Avrupa'nın sürekli olarak Türk tehdidiyle karşı karşıya kalması, Türk karakterine, Türk adetlerine karşı aşırı bir merak yarattığından, Türkleri doğal olarak, tiyatro sahnesine getirmiştir. Ayrıca, bu durum, esmer yüzü, yadırgatıcı Doğulu giyimi kuşamıyla etkileyici bir sahne dekoru oluşturulmasına da yartyordu; Türk, hainliği ve zalimliğiyle tanındı ğından en kanlı sahneleri bile inandırıcı kllıyor, putperest inanciyla bir Hıristiyan kahramanın karşısına konulduğunda da, Hıristiyanlık'a övgüler düzen dini valzlar için firsat yaratıyordu. (The Turkish lands became a focus of curiosity for Europeans with respect to the inhabitants' exotic costumes, beliefs and manners, and accounts stressed the Turks' wickedness, malice and violence which impressed and appealed to the western public. Consequently, playwrights such as Marlowe, Kyd and Shakespeare introduced Turkish figures in their works, using Turkish history as a source of material).

A complementary opinion about the creation of Turkish image is put forward by McJannet $(2006,3)$ in her preface referring to Matar's assertion "that in England, as in Spain, Portugal, France, and Italy, "the stereotype developed in literature" (specifically dramatic literature) and religious discourse "played the greatest role in shaping the anti-Muslim national consciousness":

Government documents, prisoners' depositions, and commercial exchanges show little racial, sexual, or moral stereotyping of the Muslims.... It was plays, masks, pageants, and other similar sources that developed in British 
culture the discourse about Muslim Otherness. . . . Eleazar and Othello [became] the defining literary representation of the "Moor," and Bajazeth, Ithamore, and Amureth of the "Turk."

However, there are other ideas as to how this negative image was created and intensified in the west. Robert Schwobel, (1967, I0) for instance, asserts in his work, The Shadow of the Crescent that the loss of "Constantinople" and the fear aftermath that Turks would attack Europe and destroy Christianity is the biggest factor in this creation of Turkish image.

\section{Plays Depicting Negative Images of Turks}

We know now that Turkish figures in the past were often confused with the Moor and Arabs. Although there were minorities of Arabic nations or North African nations under the reign of Ottoman Empire, they were basically Turkic tribes uniting under the flag of Ottoman Empire in Anatolia, Minor Asia and then spreading into Europe. Main plays, chronicles and travel accounts, to list some, portraying Turkic figures negatively were Robert Schwobel's The Shadow of the Crescent (1967), Richard Knolles's The Historie Of The Turkes (1603), Edward Said's Orientalism (1978), Ben Jonson'un Volpone (1605), Joseph Q. Adams's The Turke (1613), John Ford's 'Tis Pity She's A Whore (1625-1633), Thomas Dekker's Honest Whore (i604), Christopher Marlowe's Tamburlaine the Great, (1587) George Peele's Turkish Mahomet and Hyrin the Fair Greek (1594), Lodowick Carlell's Osmond the Great Turk (1638), Gibert Swinhoe's Unhappy Fair Irene (1658) anonymous Solymannidea Tragodia (I58I), Fulke Greville's Mustapha (I608) Thomas Kyd's Soliman and Perseda (I598-1599) and William Davenant's The Siege of Rhodes (I656). The negative images of Turk did not result from their ethnic or linguistic identity but mostly from their religious identity since they represented the 'Others': Muslims.

Another idea is introduced by Bassnett $(1993,99)$ in her Comparative Literature: A Critical Introduction. In reference to a recent map of Europe which appears to contradict previous ones by including Turkic or ex-Soviet republics within Europe, she criticizes "the changes of image-making and of geographies and considers actors other than the playwrights in shaping the image:" The map-maker, the translator and the travel writer are not innocent producers of text. The works they create are part of a process of manipulation that shapes and conditions our attitudes to other cultures while purporting to be something else." Some playwrights, for instance, used notes in the margins of the plays or in asides to create an extra scorn on the Turks even if they were not uttered by the actors and actresses. 
So who were the Turks they were afraid of? Were they limited to the Turks they had met in Europe and in Asia Minor or in Middle Asia steppes? In his thesis completed at University of Warwick, Aydin $($ I994, 2) highlights the unique identity of the Turks referring to Elenor Bisbee that:

Throughout Western versions of the history of the Turks within the Oriental context, Turks have never been detached from other Islamic nations of the Middle East, although they have completely different origins geographically, with a different cultural, traditional, and above all, linguistic identity. They came to Anatolia from Central Asia nine hundred years ago with their Ural-Altaic language as distinct from the Indo-European or Semitic language groups.

Although latest findings of around 35 Kurgans in the center of Istanbul may well prove that Turks might not have been invaders but residents of Istanbul as long as 3500 years ago, in this article we will be limited with the popular wisdom that Turks came to Asia Minor around IO7I5.

Westerners' position were not certain as to who they really were. Turks were often confused with Arabs until the Westerners really got into touch with the Ottoman Turks and Turkic nations of the Middle Asia where they originated from earlier than the conflict had begun. We can broadly classify their views into two broad categories: unconditional haters because of religious and political matters and others: ambiguous ones and objective ones. Were they "sensualists capable of monstrous cruelty toward Christian captives" as Erasmus represented in De bello Turcico (I530) or as McJannet (2006, I76) puts, were they: "Finally, a Pejorative epithets associated with the Ottomans in the sixteenth and seventeenth centuries included "bloody," "cruel," and "barbarous." The Turks were compared to forces of nature (whirlwinds or floods) or beasts (wolves, vipers, boars) and depicted in bestial terms such as "unbridled" or "swarming." Their rule was described as "tyranny" or a "yoke." We can encounter such negative associations even in travelers' diaries. A German traveler Dernschwam4 misunderstands the meaning of the daily call for praying from the mosques and comments that (in Çetin, 20Io, 22) “Edirne'de Türklerin hocası veya imamı günde dört defa çılkarak hu hu diye bağırlyor. Bir şeyler haykırlyor. Zaten onların başka bir şarkiları ve müzikleri dahi yok." (Dernschwam I987, 45). (In Edirne city the hodja of Turks appear four times a day and yells out meaninglessly saying "Hey hey". They have no

5 See also: Prof Erich Felgt Edward Augustos Freeman. First natives to Europe were Turks and Hungarians. We killed them. Race and Language, Part I. (Footnote I: From "Historical Essays", Third Series, I879). 
songs and no music at all). However, he doesn't know the simple fact that Mosques call for praying five times a day in that culture. For another instance the same travel writer gives false information about the practice of fasting as part of worshipping on certain days. He notes," The poverty in this country condemns them to stay hungry so they have to fast."

\section{Positive Images Stated by Famous Historical Figures}

Were they "villain, rude peasant, raging Turk, not anchored, cruel"? Of course not. Along with the ordinary westerners, there are many famous people who disprove these biased epithets. One outstanding figure is Pierre Loti (I850 - I923) (Louis Marie-Julien Viaud). However, we will list only four of the historically famous figures defining Turks. Firstly, we can cite the king of Sweden XII. Karl who said after a defeat at Poltava in I709 and taking refuge in Ottoman Empire and staying there about five years:

I was almost captured in Poltaya. It was death for me but I got away. In front of the "Bug river", it was even more dangerous; in front of me was water and behind me the enemy as burning sun on the hills... Water wanted to drown me and Sun wanted to burn me. I got away. But today I fell hostage to the Turks. Not even iron, water and fire could enslave me but they could. There's no chain on my feet and I'm not in a dungeon. I do whatever I want. This time I'm hostage to compassion and nobleness and kindness. The Turks have tied me using this diamond rope. Only if you knew how sweet it is to live as a free slave among Turks; Generous, noble, gentle.

A second figure to be noted here is Napoléon Bonaparte, French General who said: "'There are two great virtues that glorifies a human being. Man being brave, woman being fair and honest. Apart from these two there is one virtue for both men and women. To be loyal to their home and their country and even give their life for it. Turks are heroes having this virtue. Because of this, we can always kill Turks. But we can never defeat them".

Thirdly, we will quote William Martin: "Among all of the nations, the most honorable and the most friendly people are only the Turks. If you go to a Turkish village that has not been under foreign influence; you will see and learn what true hospitality is in fact". Lastly, Orientalist Alphonse de Lamartine can be read as saying, "Turks as a race and nation are the most noble and the foremost of the nations. They are socially, religiously and ethically admirable for people who are unbiased". His famous statement about the Prophet Muhammed is also considerable. He attaches great importance to 
his service for the mankind and says, "Philosopher, orator, apostle, legislator, warrior, conqueror of ideas, restorer of rational beliefs, of a cult without images; the founder of twenty terrestrial empires and of one spiritual empire, that is Muhammad. As regards all standards by which human greatness may be measured, we may well ask, is there any man greater than he".

Of course there are other examples in which even the haters of Turks had to accept some facts objectively in the plays in England. In some, for instance, Turks were portrayed (McJannet, 2-3) as forces "sent by God to teach Christian Europe about its own sins". McJannet goes on to say that there are obvious changes in the perception of Turks in time and she observes, in the early modern period, however, the Ottomans were seen as masters of a sophisticated and ably administered empire. As Barbara and Charles Jelavich (in McJannet, 2) have remarked:

The negative opinion often held of Ottoman civilization is usually based on judgments made in the I8th and Igth centuries, when the state was in a period of obvious decline. In the I5th and I6th centuries, however, Ottoman institutions may have offered the Balkan Christian a better life than he had led previously.

Although there are countless number of negative associations about Turks, why, then, there are also so many positive comments on the nature and culture of Turks. A good example is supplied through the mouth of a Venice Ambassador to Cairo who writes, in his accounts, (McJannet, 46)" ... that he never found man worthy to be compared to Selimus for justice, humanity, fortitude, and such other moral virtues: and that he was passing well nurtured and broken to all civility...". Another positive example about the manner of Turks is seen in Richard Grafton's The order of the greate Turckes Courte (London, I542), a translation of Antoine Geuffroy's L'État de la cour du gran Turc in which "Turks fascinated him by their attention to personal cleanliness (both as a prelude to prayer and after "every purgation of nature"). It will be significant to note here that as Hisar (2OI2) points out "during those days England had no indoor toilets in their houses. They used a chamber pot under one's bed at night and dispose its contents onto the streets."

Historians of the time not only praised Turks for their hygiene but also "admired the Ottomans for unity, martial excellence, and strict justice, qualities which they sometimes felt were lacking in their own societies". Almost a decade before the formal diplomatic relations were established with England in 158I, Elizabeth I corresponded with Murad III addressing him , "The Great Turk", McJannet (63) concludes that: 
Consequently, with the increasing interest in Turks and their culture, " these histories of the Turks, translated or written in English between I542 and I600, suggest that European Christians were fascinated by Ottomans and considered it important to study their history and customs." Marlowe imagined a sultan who departed from the alleged stereotype of the raging Turk and embodied the spirit (if not the letter) of the Turks' own chronicles. His play suggests that early modern drama could enter into imaginative dialogue with the Ottomans and the Muslim east in ways that even the most narrativized histories could not.

However the developing economies and emerging economies, which are focusing on their economic growth face serious challenges as they try to curb their dependence on conventional fuels. To meet emission reduction target and strengthen the alternative energy sector many of the developing economies will need large scale technology financial support from foreign countries that have advanced technologies. While countries like India and China among the developing block in Asia have made significant foray into the alternative energy sector, many of their counterparts in the region still lag far behind with regard to clean energy development. Being two economies in the region with growing share of alternative sources in the energy mix, India and China are well equipped to play critical role in strengthening the alternative energy sector in the other developing economies.

\section{Huntington's Theory Challenged}

We have almost all come to believe that there is no use putting blame on each other, accusing each other for what wrong they have done so far. Instead, we can concentrate on what contributions we can make for the future peace of the world. After so many years of Huntington's theory of 'Conflict between Cultures' several scholars put forward ideas against his theory in the hope that he may be proven wrong for the sake of the peace and understanding between religions and cultures. We are going to refer to some of them; firstly, we can cite a source to base our ideas on from the very essence of Islam, from Muhammad's Last Sermon (Farewell Sermon) according to Hadith reported in Musnad Ahmad ibn Hanbal (632 AD): "An Arab has no superiority over a non-Arab nor a non-Arab has any superiority over an Arab; also a black person has no superiority over a white person, nor a white person has any superiority over a black person, except by piety and good action. Indeed 
the best among you is the one with the best character..." ${ }^{\prime 6}$. All Muslims should take these words granted if they are true believers. Moreover, Mohammed's Last Sermon is like the Universal Declaration of Human Rights, a milestone teaching for Muslims with which they should act in conformity.

Another scholar, Murshed $(2013,22)$ of Erasmus University, Netherlands addresses to the various face of Islam as of Christianity and states, "Thus, it is conceivable for an individual to be simultaneously a Muslim, a Western citizen, a believer in democracy, as well as someone who respects difference and human rights. Furthermore, culture is not immutable; it evolves over time, and changes as material conditions alter." So, "They hate us" saying of Trump cannot be accepted and considered the speech of whole Islamic nations. Several Islamic nations enjoy a secular, relatively good democracy such as Turkey. In the same manner, in an interview conducted by J. Paul Barker $(2013,44)$ Arshin Adib-Moghaddam opposes Huntington's theory stating that:

I came to the conclusion that Huntington presented a theory of conflict nurtured by a good deal of unscholarly ignorance of other cultures. Huntington's thesis is deceptively facile. I was increasingly convinced that the clash of civilizations is one of the most inaccurate theories ever invented. Huntington was not educated in the history of Islam. In his writings he routinely conflated being Arab with being Muslim, and vice versa.

Other group of Postmodern scholars we may call 'The New Orientalists' such as Nietzsche and Foucault have logical observations about the fallacies of Christianity to the extent that they, in times, expressed their dislike and thus felt sympathy for Islam for several reasons. What are the conclusions we can draw from their positive comments on Islam and naturally Turks who have been strong representative of Islam for ages? They are some of the pioneers who have paved the ways for an intercultural/interreligious dialogue. Whether we call it 'between civilizations' or 'between East and West, between Mohammed and Christ, it is certain that we enter an age of pluralism through social media such as Facebook, Instagram and Twitter with increasing number of exchanges, even challenges between the concerned parties. Ian Almond $(2007,3)$ comments on this progress that:

6 [My translation] (Dernschwam I987:I19). Page 22 in Muslim Behaviours, Ceremonies and Religious Places According to the XVIth Century German Travellers by Firdevs Çetin Vakıflar Dergisi Y1l: Aralık 20IO - Say1: 34. See also: http://www.themodernreligion.com/prophet/prophet_lastsermon.htm.I3 See, Jeremy Salt, The Unmaking of the Middle East: A History of Western Disorder in Arab Lands, (Berkeley: University of California Press, 2008). 
Despite the wide diversity of critical approaches, a certain pattern has dictated Muslim responses to the postmodern: a sometimes free, sometimes grudging acknowledgement that postmodern thought may aid Islam in its encouragement of pluralism and challenge to European hegemony (and in particular in its deconstruction of secular nationalisms), accompanied by some distinct reservations of varying degrees with regards to the price Muslims may have to pay for this postmodern assistance in decentring the West.

Will these views and global changes solve the conflict and help improve the understanding between the civilizations? Yet, there are still some doubts on both sides.

Beginning with the establishment of the Badaliya Prayer group in Cairo in 1934 and II. Vatican Council, this dialog mission continued in Turkey when Pastor Thomas Michael visited and gave seminars in some Faculty of Theologies in 1987 trying to spread the seeds of the mission . However, on Muslim side in Turkey, in time, there appeared strong objections to the notion of 'dialogue' since it poses a 'monolog' on Muslims within Christian context. The once leading, appreciated figure foregrounding from Turkey, during $90 \mathrm{~s}$ and 20 s for interreligious dialog was Fethullah Gulen, who was later charged with terrorism and for allegedly plotting to overthrow the democratic Turkish government on the I5th July 20I6. His activities were also called 'parallel state' and he was put in the red, most wanted list of Interpol by the Turkish Government. This 15/7 coup attempt is as important for Turkey as 9/II for the USA. During the troubled previous years and later after the failed coup attempt in Turkey, some other terrorist groups such as PKK, YPG and ISIS in Iraq and Syria were created by the West, causing a new threat to the fragile regional peace. Consequently, Turkey had to launch Operation Olive Branch into Northern Syria to clear the region from US backed terrorists and restore the order along her border. These events led Turkish president Erdogan to call these terrorist affairs as "collaborators in a postmodern crusade that our region is exposed to" in the region just as how President Bush had called the 9/II 'Crusade'. It is anachronistic to watch US officials on the news stating that they support a terrorist group, YPG against another one, ISIS instead of supporting one of her best allies, Turkey. In the light of these facts, one of the major opponents of 'interreligious dialog' including Mehmet Oruc, Mehmet Bayrakdar $(2007,290)$ notes that supporters of Fethullah Gulen ${ }^{7}$ and he,

7 Fethullah Gulen was put in Interpol's red list for allegedly plotting to overthrow the Turkish government through activities of a "parallel state" against the legally elected government. He is believed to be manipulated by CIA in organizing a coup on I5th July 2016 , which failed in Turkey. 
himself pioner a view of Islam without Prophet Mohammed" and the dialog mission to which Gulen wants to serve sends an encyclical to all churches titled "Redemptoris Misso" (http://w2.vatican.va, I990, 38) in which II. John Paul defines the purpose of that mission:

Despite the wide diversity of critical approaches, a certain pattern has dictated Muslim responses to the postmodern: a sometimes free, sometimes grudging acknowledgement that postmodern thought may aid Islam in its encouragement of pluralism and challenge to European hegemony (and in particular in its deconstruction of secular nationalisms), accompanied by some distinct reservations of varying degrees with regards to the price Muslims may have to pay for this postmodern assistance in decentring the West.

This ultimate goal of the Pope must be alarming enough for a Muslim who is stuck to his religion and its prophet because essentially to be a Muslim is to address to both God and to Mohammed in the same phrase; "There is no god but God. Muhammad is God's messenger" So many scholars are in the belief that those who are in the interreligious dialogue have tried to alter the basic principles of Islamic faith. In a similar statement Mehmet Oruç (20I3, 7) states that, "Dialog and tolerance introduced recently is handled in another meaning. Rather than 'tolerance' it aims to bring together three religions on a certain axis, in such a way to unite them into a whole, which is totally the opposite what Islam has told its believers; "Islam is the last religion and Mohammed is the last Prophet". How will the process continue in the light of these above mentioned facts remain unanswered although there are some good will prescriptions.

One of the most important suggestions from the Turkish side to restore the peace between the parties comes from Mahmut Aydın (2002, I3) who states that "this Islamic background of Turkey as an advantage, since the Turkish Islamic mentality could be a means for peace between Muslims and others by accepting Turkey into the European Union, the Christian West might show its own sincerity about entering into dialogue with Muslims and

8 An encyclical given in Rome, at St. Peter's, on December 7, the twenty-fifth anniversary of the Conciliar Decree Ad Gentes, in the year I990, the thirteenth of my Pontificate. See: https://en.wikipedia.org/wiki/Redemptoris_missio.

9 This sentence, the shortest form of the Islamic Declaration of faith or testimony (shahādah) means: "There is no deity (God, ilāh in Arabic) but the One and Only God (Alläh in Arabic); no-one is to be worshipped but God (Allāh) alone. - Muhammad is God's messenger (to mankind)." This short formula is sometimes called the kalima (literally, "word") or the kalimat at-tauhīd ("the word of confession of [God's] Oneness"); kelime-i tevhîd in Turkish. 
showing Muslims that the European Union is not necessarily a Christian Club". Turkish constitution article Io is in conformity with Western values. It writes "Everyone is equal before the law without distinction as to language, race, color, sex, political opinion, philosophical belief, religion and sect, or any such grounds".

From the socio-politic view point, Turkey is an irreplaceable future partner both for Europe and the USA. Latest report published by European Commission $(2017, \mathrm{I} 3)$ states that within the framework of accession negotiations, I 6 chapters have been opened so far and concludes that to ensure the full and sustained implementation of the EU-Turkey Statement requires continuous efforts and political determination from all sides. The EU and the USA seem unaware of the fact that Turkey secures NATO and European borders against terrorist attacks and refugee flood into the Union.

\section{Conclusions}

For the present status of Turkey, it should, first, always be kept in mind that as a secular and modern Turkey, her contributions to the future process of world peace, in any way whatsoever it may be called, is globally vital. Just to remind how important Turkey representing Muslims is that after the First World War Mustafa Kemal Ataturk willingly abolished the Caliphate on March 3, I924 while, still today, the Pope and some other Western Monarchies such as The Queen Elizabeth, The King of Spain etc., enjoy their title. Muslims have recognized and have had faith in all prophets including Jesus Christ from the beginning. However Christians, "for the first time in the history of Christianity, in Vatican Council, non-Christian religions were officially considered as entities which Christians should respect and seek to discover". In the past many considered Mohammed as a terrorist or even accused him of creating a sect of Christianity. "In Western Europe, down to the I3th century or so, Christians had a mistaken belief that Muhammad had either been a heretical Christian or that he was a god worshipped by Muslims. Some works of Medieval European literature referred to Muslims as "pagans" or by sobriquets such as the "paynim foe" (enemy)". My personal statement about the conflict from the beginning is that it all 'raison d'etat'. We cannot reduce the issue to the 'expansion' of Muslim Turks since there are views previously stated that they were early settler of Europe together with Hungarians. Secondly, many scholars note that there is also polarization in Turkey between the parties; Laicists and Islamists, on the way to modernity and it is not easy to solve it even within Turkey. So which party will dominate in the future and represent Turkey in the interreligious dialogue is not certain. Çarkoglu 
and Toprak (2007, I04) find out in their study that "Turkey seems to harbor two widely divergent societies that are clearly separated from each other. On one side are urban, better-educated people with a relatively high income level who do not feel extremely committed to religious values and who define themselves as secular; and on the other side are rural, less-educated people with a relatively low income level and who define themselves as Islamist and religious." Both parties resent with the view that Turkey does not belong and deserve to be a European Union member. Like Huntington's and other pessimistic views that there is long way for Christians and Muslims to understand each other Çoban $(2008$, I06) in his study of two missionaries E.M. Wherry and Ron Peck about Islam observes the same reality that "living together is a dream". It should be noted that there is a hundred years in time between these two missionaries and the question is still at the door. Instead of taking a pessimistic point of view we should, as (Çatalbaş and Çetinkaya, 6) suggest "Christian-Muslim dialogue should be organised by official institutions in Turkey and should be practiced by experts who know Christianity very well". However, on the brink of the new millennium, new actors such as the USA is pushing the matter into a darker aspect declining herself a God like decision maker.

About this new threat Falk (2004, 2I9) observes that “...removing the threat of global fascism would not entirely dispose of the existence of an American empire. There would still be the advocates of benevolent empire and the structural possibilities of reviving an economistic approach to globalization as it existed in the I990s" and thus, he comes to "the unhappy conclusion that the danger we and the world faces is the distinct possibility that American foreign policy, as now practiced, and to the extent it is successful, will eventuate in a form of world order best described as "global fascism" $(2000,260)$. As the welfare of Turkish people increases, the gap between religion and politics will be closed and solving the problems between the social structures will become easier. I will take the standpoint of Aydın here as we end our article "instead of making dogmatic claims about our faiths, we need to prove their quality in practice".

\section{REFERENCES}

Aksoy, Nazan. 2004. Rönesansingilteresinde Türkler. İstanbul: Çağdaş Yayınlarl.

Almond, Ian. 2007. The New Orientalists: Postmodern Representations of Islam 
Turkish Image in the West During the Ottoman Empire: Historical Facts and Present Day Connotations

from Foucault to Baudrillard I.B.Tauris \& Co. Ltd.

Aydın, Kamil. I994. (Atatürk University, Erzurum). Turkey as Represented in English Literature of the time. Ph.D. thesis completed at University of Warwick.

Aydın, Mahmut. 2002. Modern Western Christian theological understandings of Muslims since the Second Vatican Council. Cultural Heritage and Contemporary Change. The Council for Research in Values and Philosophy. Series IIA, Islamic Philosophical Studies, Volume I3. Washington, D.C.

Barker, J. P. 20I3. The Clash of Civilizations Twenty Years On. Bristol: E-International Relations Edited Collections. pp.43-51.

Bassnett, Susan. I993. Comparative Literature: A Critical Introduction. Oxford: Blackwell.

Bayrakdar, Mehmed 2007. Dinler Arası Diyalog ve Başkalaştırlan İslam. The Interreligious Dialogue and Islam Metamorphosing. Journal of Islamic Research, 20.

Çarkoğlu, Ali and Binnaz Toprak. 2007. RELIGION, SOCIETY AND POLITICS IN A CHANGING TURKEY. TESEV PUBLICATIONS: Turkish Economic and Social Studies Foundation Democratization Program. Translated from Turkish by Çiğdem Aksoy Fromm. Edited by Jenny Sanders. Sena Ofset. İstanbul.

Çatalbaş, Resul and Kenan Çetinkaya. 20I5. Interreligious dialogue in the views of Turkish historians of religions. Teologiese Studies/Theological Studies 7I, 3. https://doi.org/I0.4IO2/hts.v7Ii3.2896.

Çetin, Firdevs. 20I0. XVI. Asır Alman Seyyahlarına Göre Osmanlı Toplumu. (Müslüman Davranışv ve Törenleri ile Dini Mekânlar). Muslim Behaviours, Ceremonies and Religious Places. According to the XVIth Century German Travellers. Vakıflar Dergisi. Y1l: Aralık 2010. Say1 34. Sayfa: 19-34

Çoban, Bekir Zahir 2008. TÜRKLERIN DINI'NDEN HILALIN GÖLGESI'NE VEYA KIBIRDEN KORKUYA: 1896 VE 1995 AMERIKA'SINDAN IKI FARKLI ISLAM ALGISI. DEÜIFD, XXVII/2008, 91-Io6.

Dernschwam, H. I987. IIstanbul ve Anadolu'ya Seyahat Günlügü. çev. Yasar Önen, Ankara: Kültür ve Turizm Bakanlığı Yayınları.

European Commission. 20I7. REPORT FROM THE COMMISSION TO THE EUROPEAN PARLIAMENT, THE EUROPEAN COUNCIL AND THE COUNCIL Seventh Report on the Progress made in the implementation of the EU-Turkey Statement, Brussels, 6.9.20I7 COM(20I7) 
470 final.

Falk, Richard A. 2000. Predatory Globalization: A Critique (Cambridge: Polity, 2000); also Michael Hardt and Antonio Negri, Empire (Cambridge, Mass.: Harvard University Press).

Falk, Richard A. 2004. The declining world order : America's imperial geopolitics. Taylor and Francis Books, Inc. Routledge. New York, NY.

Halid, Halil. 20I3. Journal of History School (JOHS) XVI, 6, 749-75. Reporting: Mustafa MALHUT.

McJannet, Linda. 2006. The Sultan Speaks: Dialogue in English plays and histories about the Ottoman Turks. Palgrave McMillan. New York.

Murshed, S. M. 20I3. The Crescent and the Cross. In The Clash of Civilizations Twenty Years On, editted by J. Paul Barker, 20-27. Bristol: E-International Relations. Edited Collections.

Oruç, Mehmet. 2003. DINLERARASI DIYALOG TUZAGIĞI ve Dinde Reform. Ar1 Sanat Yayınevi. İstanbul.

Özakıncı, Cengiz. “Tarih Tezleri Çarpışıyor: AVRUPALI'LARIN ATALARI TÜRK'TÜR” (Mart, 2002): 67-92. Otopsi. Bütün Dünya 2000. Başkent Üniversitesi Kültür Yayını. Ankara.

Peck, Ron. 1995. The Shadow of the Crescent. The Growth of Islam in the United States. CMM. Springfield, MO.

Said, W. Edward. I977. Orientalism. Harmondsworth: Penguin Books. In Christopher Marlowe (1969; 1980).

Schweigger, S. 2004. Sultanlar Kentine Yolculuk I578-I58I, çev. S. Türkis Noyan, İstanbul: Kitap Yayınevi.

Schwoebel, Robert. 1967. The Shadow of the Crescent: The Renaissance Image of the Turk (1453-1517). New York: St. Martin's Press.

Şenlen, Sila, 2006. "Ottoman Sultans in English Drama Between 1580-1660", OTAM.I9. Ankara: Ankara Basimevi, 399-405.

Widmer, Ted. 20Io. The Founding Fathers Weren't Anti-Islam. http://washingtonsblog.com/2010/09/the-founding-fathers-werent-anti-islam. html. Accessed on: December 22, 2017. 


\section{ABSTRACT}

Throughout history there have been opposing forces, one of which is the conflict between 'West and East' as Huntington claims. One of the earliest, major competitions, in this matter, has been the one with Ottoman Empire, representing Islam and European countries, followers of Christianity. These forces have been clashing in the form of several means and for reasons to predominate each other if they can achieve it at all. How has such a 'clash' begun between civilizations and what is the present status of it between Turkey and Western countries? This study aims at highlighting the background from a historical point of view beginning with the capture of Jerusalem by Ottoman Turks and how Turkish Image is created and portrayed in Early English Plays in relation to the rise and fall of Ottoman Empire as depicted in The Sultan Speaks by Linda McJannet. Since the core of the Ottoman Empire is modern Turkey today, the recent changes in their image on the way to full membership to the EU as well as to 'interreligious/intercultural dialog' in an attempt to bring peace to both parties in question for a sustainable and amicable future. It is concluded that there are still concerns between the global signatories. It will take some more time and effort to mature the thinking that they could live harmoniously developing their countries economically and their democracies for a mutual understanding.

\section{KEYWORDS}

Turkish Image, Early Modern Plays, Ottoman Empire, Islam, Turks.

Received on May 19, 2018. Accepted on July 7, 2018. 